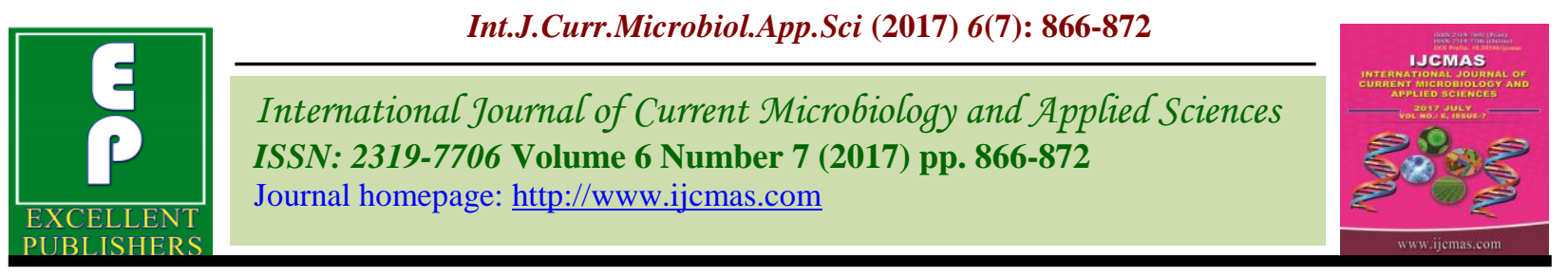

Original Research Article

https://doi.org/10.20546/ijcmas.2017.607.106

\title{
Perception and Usefulness of Mobile Phone Based Agro-Advisories (MBAs)
}

\author{
K. Madan Mohan Reddy ${ }^{*}$, I. Sreenivasa Rao ${ }^{1}$, M. Srinivasulu ${ }^{1}$ and G. D. Satish Kumar ${ }^{2}$ \\ ${ }^{1}$ Department of Agricultural Extension, College of Agriculture, Professor Jayashankar Telangana \\ State Agricultural University (PJTSAU), Hyderabad-30, Telangana, India \\ ${ }^{2}$ Indian Institute of Oilseed Research, Hyderabad-30, Talangana, India \\ *Corresponding author
}

\section{A B S T R A C T}

\begin{tabular}{|c|c|}
\hline Keywords & \\
\hline $\begin{array}{l}\text { Information and } \\
\text { communication } \\
\text { technology (ICT), } \\
\text { Mobile Phone } \\
\text { Based Agro- } \\
\text { Advisories } \\
\text { (MBAs), } \\
\text { Perception, } \\
\text { Usefulness. }\end{array}$ & $\begin{array}{l}\text { developing countries today is the mobile phone. Mobile phones are the devices } \\
\text { that can create, store, access, and share information anytime, anywhere. But they } \\
\text { are more than that, when teamed with extension and advisory services, they can } \\
\text { help improve the livelihoods of rural people by getting much needed timely } \\
\text { information to their fingertips at potentially low cost. The present study was } \\
\text { carried out in Warangal district of Telangana state by selecting the } 60 \text { beneficiary } \\
\text { farmers of mobile phone based agro-advisory services. The specific objectives of } \\
\text { the studv were to know the usefulness and nercention towards mobile phone based }\end{array}$ \\
\hline Article Info & agro advisories. The results showed that 48.33 per cent of respondents indicated as \\
\hline $\begin{array}{l}\text { Accepted: } \\
\text { 14 June } 2017 \\
\text { Available Online: } \\
\text { 10 Julv } 2017\end{array}$ & $\begin{array}{l}\text { mobile phone based agro-advisories were moderately useful and the majority } \\
(50.00 \%) \text { of the respondents had positive perception towards the mobile phone } \\
\text { based agro-advisories. }\end{array}$ \\
\hline
\end{tabular}

Introduction

The most widespread information and communication technology (ICT) in developing countries today is the mobile phone. Mobile phones are the devices that can create, store, access, and share information anytime, anywhere. But they are more than that, when teamed with extension and advisory services, they can help improve the livelihoods of rural people by getting much needed timely information to their fingertips at potentially low cost. A number of pilot experiments/studies in the use of mobile telephones in development sector have emphasized its potential and relevance in agriculture and rural development sector although a suitable framework still needs to be evolved for its efficient and sustained use in agriculture information dissemination. For example, we need to evolve an information delivery mechanism so that farmers can take major agricultural decisions such as timely soil preparation, time of sowing, appropriate doses of fertilizers, irrigation scheduling, weeding, harvesting, and storage and marketing which have been of key concern to farmers. To provide information on these aspects the existing extension staff is very limited. According to estimates, on average 
public extension personnel spends 40 minutes per year for a farmer (Dileepkumar, 2012). So called Mobile Phone Based Agro-Advisory Services are the part of ICT initiative which enables value added services, such as timely advisories to the farmers which helps to monitor their crops, livestock and farm machinery through mobile phones. Pawan Kumar (2011) reported that the information obtained through mobile phones improved soil health, which resulted in increased agricultural productivity and farm income. Rizvi (2010) observed that access to mobile based advisory services can help to reach poor farmers in remote/rural areas. Among one of the most celebrated of such studies is the Jayanthi (2016) observed that about threefifths $(61.25 \%)$ of the respondents had medium level of information seeking behaviour, medium perception (74.17\%) towards mobile agricultural extension services and she also found that in total 57.50 per cent of the respondents reported that mobile agricultural extension services were useful towards mobile agricultural extension services. Kumar and Padmaiah (2012) reported significant improvements in knowledge of castor growers due to mobile phone based agro-advisories.

There is need to study the perception and usefulness of Mobile Phone Based Agroadvisories (MBAs) by the farmers. In this context, a study has been planned with the following objectives:

To study the profile characteristics of the respondents.

To study the Perception and Usefulness of Mobile Phone Based Agro-advisories (MBAs) by the respondents.

\section{Materials and Methods}

The 'Ex post- facto 'research design was adopted for the study. The study was conducted in Warangal district of Telangana State, where the farmers were received SMS/Voice messages from the various mobile phone based agro-advisory services. A sample of 60 beneficiary farmers was selected by using random sampling method. A wellstructured interview schedule was used to collect the data according to the objectives of the study. Statistical tools like mean, frequency and percentages were used for analysis of data.

\section{Results and Discussion}

\section{Profile characteristics of the respondents}

The findings presented in table 1 indicated that more than half of farmers belonged to middle age group $(65.00 \%)$ followed by young $(25.00 \%)$ and old $(10.00 \%)$ age group. The probable reason might be that, most of the old age people were not interested to use mobile phones and middle age farmers were enthusiastic to use mobile phones for getting information related to agriculture. Majority (31.67\%) of the respondents had intermediate education followed by 23.33 per cent farmers had high school education, 20.00 per cent farmers had graduates education, 15.00 per cent farmers had upper primary school education, only 6.67 per cent farmers had primary school education, very few 3.33 per cent farmers were post graduates and there is no illiterates. This might be due to that farmers have easy access to schools and realization of importance of formal education in the present situation. As they had education, they were able to gather knowledge on recent technologies disseminated through Mobile Phone Based Agro Advisory Services. Generally, in the present scenario, almost everybody is found to be literate due to the awareness brought by the government on the importance of education and the efforts of the government and non - governmental agencies. Majority 
$(53.33 \%)$ of the farmers were comes under large farmers followed by small $(33.33 \%)$ and Marginal (13.33). This may be because of the majority of farmers who effectively using Mobile Phone Based Agro Advisory Services were only large farmers. It was observed that 40.00 per cent of the farmers had medium extension contact while 35.00 per cent of the farmers high extension contact and 25.00 per cent of the participants had low extension contact. The probable reason for this might be their eagerness in solving their cultivation problems with extension workers and also interest in extension activities to gather recent information. A little more than half $(60.00 \%)$ of the farmers had medium level of information seeking behaviour followed by low (31.67\%) and high (8.33\%) levels of information seeking behaviour. The probable reason might be that, the farmers rely more on neighbours, friends, relatives, progressive farmers and input dealers for information rather than formal sources. Majority $(55.00 \%)$ of the respondents had medium information management behaviour followed by high $(28.33 \%)$ and low $(16.67 \%)$. This might be due to high information evaluation by cross checking the data with past experience; friends, input dealers and they might see the perceived attribute of the technology received from the mobile phone based agro advisory services. Majority (58.33\%) of the people had medium innovativeness followed by high (23.33\%) and low (18.33). The reason might be respondents might be having higher education, high land holding and considerably good percentage of information seeking behaviour and information management behaviour.

Perception of the respondents towards Mobile Phone Based Agro-advisories (MBAs)

From the table 2, it is indicated that more than half of the farmers $(73.33 \%)$ thought that the messages were presented in time coinciding with the crop growth and 18.33 per cent of the farmers felt, messages were late. The probable reason might be that he farmers, who had sown the crop early in kharif felt that the messages were late. Very few farmers $(8.33 \%)$ were felt messages were early. Majority of the farmers $(58.33 \%)$ reported that the content of the messages was highly relevant, easy to understand (68.33\%), messages were highly technical (51.67\%) and content was adequate $(55.00 \%)$.

\section{Overall perception of the respondents towards MBAs}

It was observed from table 4, that exactly half i.e. 50.00 per cent of the respondents had positive perception towards the mobile phone based agro-advisories followed by 30.00 per cent and 20.00 per cent of the respondents with neutral and negative perception, respectively.

The probable reason for positive perception towards mobile phone based agro-advisories due to the farmers were getting timely, highly relevant messages from mobile phone based agro advisory services based on their needs. Further the mobile phone based agroadvisories were highly treated, easy to understand and having adequate content.

\section{Usefulness of Mobile Phone Based Agro- advisories (MBAs) by the respondents}

Majority $(71.67 \%)$ of farmers felt that as mobile phone based agro-advisories (MBAs) were 'most useful' for improving the agriculture knowledge followed by useful $(25.00 \%)$ and not useful (3.33\%). Most of the farmers indicated that the MBAs were useful $(50.00 \%)$ where the farmers decide on what crop to grow, how much land to allocate for each crop followed by most useful $(45.00 \%)$ and not useful (5.00). Majority i.e. 60.00 
percent of the farmers were felt MBAs were useful followed by most useful $(23.33 \%)$ and not useful $(16.66 \%)$ while seed purchase and seed bed preparation. During the land preparation and planning MBAs were useful (46.66\%) followed by most useful $(43.33 \%)$ and not useful $(10.00 \%)$. Mobile phone based agro-advisories were useful $(73.33 \%)$ in nutrient management followed by most useful $(21.66 \%)$ and not useful (5.00\%). Most of the respondents reported that MBAs on plant protection were most useful (73.33\%) followed by useful $(23.33 \%)$ and not useful (3.33\%). During the harvesting/picking and storing time the MBAs were most useful $(56.66 \%)$ followed by useful $(40.00 \%)$ and not useful $(16.66 \%)$. Mobile phone based agro-advisories were most useful $(43.33 \%)$ while selling the produce followed by useful $(40.00 \%)$ and not useful (16.66\%). For creating awareness about new technologies these MBAs were useful $(55.00 \%)$ followed by not useful $(30.00 \%)$ and useful $(15.00 \%)$. Majority of the farmers felt mobile phone based agro-advisory services provide most useful $(53.33 \%)$ information on extension activities followed by useful $(26.66 \%)$ and not useful $(20.00 \%)$.

Table.1 Distribution of the respondents according to their profile characteristics

\begin{tabular}{|c|c|c|c|c|}
\hline S. No. & Variables & Category & Frequency & Percentage \\
\hline \multirow[t]{3}{*}{1.} & \multirow[t]{3}{*}{ Age } & $\begin{array}{c}\text { Young } \\
\text { (Upto } 35 \text { years) }\end{array}$ & 15 & 25.00 \\
\hline & & $\begin{array}{c}\text { Middle } \\
\text { (36-50 years) }\end{array}$ & 39 & 65.00 \\
\hline & & $\begin{array}{c}\text { Old } \\
\text { (Above } 50 \text { years) }\end{array}$ & 06 & 10.00 \\
\hline \multirow[t]{7}{*}{2.} & \multirow[t]{7}{*}{ Education } & Illiterate & 00 & 0.00 \\
\hline & & Primary School & 04 & 06.67 \\
\hline & & Upper Primary School & 09 & 15.00 \\
\hline & & High School & 14 & 23.33 \\
\hline & & Intermediate & 19 & 31.67 \\
\hline & & Graduation & 12 & 20.00 \\
\hline & & Post-Graduation & 02 & 03.33 \\
\hline \multirow[t]{3}{*}{3.} & \multirow[t]{3}{*}{ Farm Size } & Marginal & 08 & 13.33 \\
\hline & & Small & 20 & 33.33 \\
\hline & & Large & 32 & 53.33 \\
\hline \multirow[t]{3}{*}{4.} & \multirow[t]{3}{*}{ Extension Contact } & Low & 15 & 25.00 \\
\hline & & Medium & 24 & 40.00 \\
\hline & & High & 21 & 35.00 \\
\hline \multirow[t]{3}{*}{5.} & \multirow{3}{*}{$\begin{array}{c}\text { Information Seeking } \\
\text { Behaviour }\end{array}$} & Low & 19 & 31.67 \\
\hline & & Medium & 36 & 60.00 \\
\hline & & High & 05 & 8.33 \\
\hline \multirow[t]{3}{*}{6.} & \multirow{3}{*}{$\begin{array}{c}\text { Information } \\
\text { Management Behaviour }\end{array}$} & Low & 10 & 16.67 \\
\hline & & Medium & 33 & 55.00 \\
\hline & & High & 17 & 28.33 \\
\hline \multirow[t]{3}{*}{7.} & \multirow[t]{3}{*}{ Innovativeness } & Low & 11 & 18.33 \\
\hline & & Medium & 35 & 58.33 \\
\hline & & High & 14 & 23.33 \\
\hline
\end{tabular}


Table.2 Perception of the respondents towards Mobile Phone Based Agro-advisories

\begin{tabular}{|c|c|c|c|}
\hline \multirow[t]{2}{*}{ Variables } & \multirow[t]{2}{*}{ Categories } & \multicolumn{2}{|c|}{ Cotton farmers } \\
\hline & & $\mathbf{F}$ & $\mathbf{P}$ \\
\hline \multicolumn{4}{|c|}{ a. Timeliness of the messages } \\
\hline & $\begin{array}{l}\text { Coinciding with the crop } \\
\text { growth }\end{array}$ & 44 & 73.33 \\
\hline & Early & 05 & 08.33 \\
\hline & Late & 11 & 18.33 \\
\hline \multicolumn{4}{|l|}{ b. Relevance } \\
\hline & Highly relevant & 35 & 58.33 \\
\hline & Somewhat relevant & 14 & 23.33 \\
\hline & Irrelevant & 11 & 18.33 \\
\hline \multicolumn{4}{|c|}{ c. Understanding of message } \\
\hline & Easy to understand & 41 & 68.33 \\
\hline & Difficult to understand & 13 & 21.67 \\
\hline & Not understand & 06 & 10.00 \\
\hline \multicolumn{4}{|c|}{ d. Message treatment } \\
\hline & Less technical & 11 & 18.33 \\
\hline & Moderately technical & 18 & 30.00 \\
\hline & Highly technical & 31 & 51.67 \\
\hline \multicolumn{4}{|c|}{ e. Content adequacy } \\
\hline & Adequate & 33 & 55.00 \\
\hline & Needs more details & 17 & 28.33 \\
\hline & Not at all adequate & 10 & 16.67 \\
\hline
\end{tabular}

Table.3 Usefulness of Mobile Phone Based Agro-advisories (MBAs) by the respondents

\begin{tabular}{|c|c|c|c|c|c|c|c|}
\hline \multirow{4}{*}{$\begin{array}{l}\text { S. } \\
\text { No. }\end{array}$} & \multirow{4}{*}{ Particulars } & & & & & & $=60$ \\
\hline & & \multicolumn{6}{|c|}{ Level of Usefulness } \\
\hline & & \multicolumn{2}{|c|}{ Most Useful } & \multicolumn{2}{|c|}{ Useful } & \multicolumn{2}{|c|}{ Not Useful } \\
\hline & & $\mathbf{F}$ & $\mathbf{P}$ & $\mathbf{F}$ & $\mathbf{P}$ & $\mathbf{F}$ & $\mathbf{P}$ \\
\hline 1. & $\begin{array}{l}\text { Improving the Knowledge in } \\
\text { Agriculture }\end{array}$ & 43 & 71.67 & 15 & 25.00 & 02 & 3.33 \\
\hline 2. & Decision to choose crop & 27 & 45.00 & 30 & 50.00 & 03 & 5.00 \\
\hline 3. & $\begin{array}{l}\text { Seed Purchase and seed bed } \\
\text { preparation }\end{array}$ & 14 & 23.33 & 36 & 60.00 & 10 & 16.66 \\
\hline 4. & Land Preparation and planting & 26 & 43.33 & 28 & 46.66 & 06 & 10.00 \\
\hline 5. & Nutrient Management & 13 & 21.66 & 44 & 73.33 & 03 & 5.00 \\
\hline 6. & $\begin{array}{l}\text { Effective in Plant Protection } \\
\text { Measures }\end{array}$ & 44 & 73.33 & 14 & 23.33 & 02 & 3.33 \\
\hline 7. & Harvesting/Picking and Storing & 34 & 56.66 & 24 & 40.00 & 02 & 3.33 \\
\hline 8. & Selling of Produce & 26 & 43.33 & 24 & 40.00 & 10 & 16.66 \\
\hline 9. & $\begin{array}{l}\text { Creating awareness about new } \\
\text { technologies }\end{array}$ & 09 & 15.00 & 33 & 55.00 & 18 & 30.00 \\
\hline 10. & $\begin{array}{l}\text { Information on Extension } \\
\text { Activities }\end{array}$ & 32 & 53.33 & 16 & 26.66 & 12 & 20.00 \\
\hline
\end{tabular}


Table.4 Overall Perception of the respondents on Mobile Phone Based Agro-Advisories

\begin{tabular}{|c|c|c|c|}
\hline \multirow{2}{*}{ S.No. } & \multirow{2}{*}{ Category } & \multicolumn{2}{|c|}{$\mathrm{n}=60$} \\
\cline { 3 - 4 } & & Frequency & Percentage \\
\hline 1. & Positive Perception & 30 & 50.00 \\
\hline 2. & Neutral Perception & 18 & 30.00 \\
\hline 3. & Negative Perception & 12 & 20.00 \\
\hline
\end{tabular}

Table.5 Overall usefulness of Mobile Phone Based Agro-advisories by the respondents

\begin{tabular}{|c|l|c|c|}
\hline \multirow{2}{*}{ S.No. } & \multirow{2}{*}{ Category } & \multicolumn{2}{c|}{$\mathrm{n}=60$} \\
\cline { 3 - 4 } & & Frequency & Percentage \\
\hline 1. & Less useful & 12 & 25.00 \\
\hline 2. & Moderate useful & 29 & 48.33 \\
\hline 3. & Most useful & 19 & 26.67 \\
\hline
\end{tabular}

Table.6 Relationship between Profile characteristics of the respondents and Their Perception towards MBAs

\begin{tabular}{|c|l|c|}
\hline S. No. & \multicolumn{1}{|c|}{ Profile characteristics } & Correlation coefficient (r) \\
\hline 1. & Age & $-0.237^{*}$ \\
\hline 2. & Education & $0.562^{* *}$ \\
\hline 3. & Farm size & $0.715^{* *}$ \\
\hline 4. & Extension contact & $0.614^{* *}$ \\
\hline 5. & Information Seeking Behaviour & $0.438^{* *}$ \\
\hline 6. & Information Management Behaviour & $0.294^{* *}$ \\
\hline 7. & Innovativeness & $0.624^{* *}$ \\
\hline
\end{tabular}

** Significant at the 0.01 level; * Significant at the 0.05 level; NS = Non-Significant

Overall usefulness of Mobile Phone Based Agro-advisories by the respondents

It could be noted from table 5 and that, 48.33 per cent of farmers indicated as Mobile Phone Based Agro-advisories were moderately useful to them followed by most useful $(26.67 \%)$ and less useful $(25.00 \%)$.

It could be seen from table 5, majority of the respondents belonged to medium and high usefulness. The possible reasons could be majority of the respondents found the information was 'most useful' because subject areas covered in mobile phone based agroadvisories were most relevant to their situation and with good educational background of the farmers they are very much interested in the new technologies disseminated through mobile phone based agro-advisory services. Messages related to pant protection were most useful but few stated that lack of interest due to lengthy text and lack of specific information and difficult to understand technical words were 
reasons for finding the information as 'less useful' (Table 3).

\section{Relationship between Profile characteristics of the respondents and their Perception towards Mobile Phone Based Agro- advisories (MBAs)}

In order to study the relationship between the perceptions towards mobile phone based agroadvisories and the profile characteristics of the respondents, the correlation co-efficient (r) values were computed and findings were furnished here under table 6 .

The finding of the table 6 revealed that variables such as education, farm size, extension contact, information seeking behaviour and innovativeness had positive and significant relationship with perception of respondents at one per cent level of significance.

Whereas, information management behaviour had positive and significant relationship with perception of respondents at five per cent level of significance. As far as age was concerned, it had negative and significant relationship with attitude of farmers at five per cent level of significance.

In conclusion, this study has clearly bought out the use of mobile phone networks for dissemination of agricultural knowledge as one of the powerful means of increasing access to quality information to farmers who may not be reached by the extension programmes. With the increased availability, access and ownership of mobile phones in India, mobile based agroadvisories would play a significant role in reducing the information gap and information asymmetry between the farmers. It can be concluded that mobile phones based agro- advisories were useful, create awareness and make knowledge accessible to farmers.

\section{References}

Dileepkumar, G. 2012. ICT Innovations for Agriculture and Rural Development. Presented in the $8^{\text {th }}$ Convention of Grameen Gyan Abhiyan-Rural Knowledge Movement, Role of ICT in Rural Transformation, M.S. Swaminathan Research foundation, Chennai, October $28-29^{\text {th }}, 2012$.

Jayanthi, M. 2016. Impact of ICT enabled Agricultural Extension Services among farmers in Tamil Nadu. Ph.D. Thesis. Centre for Agricultural and Rural Development Studies, TNAU, Coimbatore.

Kumar, G. D. S. and Padmaiah, M.2012. Mobile basedagro-advisories on castor and sunflower. In: Proceedings of $8^{\text {th }}$ Convention of Grameen Gyan Abhiyan: Rural Knowledge Movement, 28-29 October, 2012 by the M. S. Swaminathan Research Foundation at MSSRF, Chennai, India.pp:14-15.

Pawan Kumar.2011. ICT for Rural prosperityan ICT mobile based information technology for improving farmers' livelihoods. In: Proceedings of Mobile plus International conference, 1517Septernber, 2011 by the M S Swaminathan Research Foundation at MSSRF, Chennai, India. pp.14.

Rizvi, S. M. H., 2010, Livelihood Solutions through Mobile Technology: An Assessment Technical Paper No. 1. Rural Research Centre, Institute of Rural Research and Development (IRRAD), Gurgaon, Haryana (India).

\section{How to cite this article:}

Madan Mohan Reddy, K., I. Sreenivasa Rao, M. Srinivasulu and Satish Kumar, G.D. 2017. Perception and Usefulness of Mobile Phone Based Agro-Advisories (MBAs). Int.J.Curr.Microbiol.App.Sci. 6(7): 866-872. doi: https://doi.org/10.20546/ijcmas.2017.607.106 